\title{
Harvard, the Chicago Tradition, and the Quantity Theory: A Reply to James Ahiakpor
}

\author{
David Laidler and Roger Sandilands
}

James Ahiakpor's critique of our work (Laidler and Sandilands 2002a) on some specific links between monetary thought at Harvard and Chicago in the early 1930s is wide ranging and provocative. He makes much of the indisputable, and undisputed (certainly by us), point that monetary thought in both places drew on a common quantity-theoretic heritage whose lineage can be traced back at least to David Hume (1752). But he goes further than this, suggesting that this common heritage alone, rather than any more direct influence, links the contents of a memorandum prepared at Harvard in January 1932 by Lauchlin Currie, Paul T. Ellsworth, and Harry D. White (Laidler and Sandilands 2002b), which, alongside proposals for dealing with international indebtedness, urged the implementation of domestic antidepression policies based on monetary and fiscal expansion, and the well-known manifesto bearing similar messages that emerged from a conference held at the University of Chicago later that month under the auspices of the Harris Foundation.

Ahiakpor notes that "Milton Friedman had the occasion to point to the common theoretical heritage for the Harvard and Chicago documents, but did not" and then tells his readers that his own paper "seeks to fill

Correspondence may be addressed to David Laidler, Department of Economics, University of Western Ontario, London, Canada N6A 5C2 (e-mail: laidler@uwo.ca); or to Roger Sandilands, Department of Economics, University of Strathclyde, 130 Rottenrow, Glasgow G4 0GE, Scotland (e-mail: r.j.sandilands@strath.ac.uk).

History of Political Economy 42:3 DOI 10.1215/00182702-2010-026

Copyright 2010 by Duke University Press 
the gap" that Friedman left. Had Ahiakpor paused to consider why so resourceful and enthusiastic a controversialist as Friedman failed to grasp this apparent opportunity, however, he might have noticed that his own supposedly gap-filling arguments, far from damaging the case we made, simply miss the point of our case at a number of crucial stages. The fact that Friedman did see that point, we conjecture, explains why he did not advance any arguments like Ahiakpor's.

In what follows, we shall argue successively the following: (1) that Ahiakpor has misunderstood how our work fits into the debate about the significance of the so-called Chicago tradition for the economic thought of the 1930s; (2) that he has confused conventional quantity-theoretic analysis of the transmission mechanism linking changes in the quantity of money to changes in such real variables as output and employment, as well as to the price level, with the forced-saving doctrine that in the 1930s had come to play a central role in the fundamentally antiquantity-theoretic economics of such "Austrian" thinkers as Friedrich von Hayek, Ludwig von Mises, and Lionel Robbins, which was represented at the Harris conference by Gottfried von Haberler; and (3) that he has underestimated the influence on contemporary policy of exponents of the "needs of trade" theory of monetary policy, represented at the Harris conference by Henry Parker Willis, and has failed to appreciate the central weakness of the slightly later Harvard volume on the economics of the recovery program (Brown et al. 1934) and the importance of this weakness for the subsequent development of macroeconomics at that university.

\section{The Debate about the Chicago Tradition}

Debate about the so-called Chicago tradition has by now gone on with varying intensity for more than half a century and has generated a literature far too voluminous and complex to survey here. A brief summary of some of its salient features is, however, required. Its starting point was Milton Friedman's (1956) claim that from the 1930s onward, the University of Chicago had been home to an oral tradition centered on a version of the quantity theory of money formulated not as a theory linking the behavior of prices to the supply of money, but as a theory of the demand for money. After an unfortunately long time-lag, Don Patinkin (1969) would dispute this claim, arguing that the 1930s Chicago tradition as evidenced 
in his own lecture notes, and in the written record, was grounded in a traditional, essentially, as he saw it, Fisherian version of the quantity theory. ${ }^{1}$ More controversially, he also suggested that Friedman's 1956 "Restatement" bore more resemblance to Keynes's theory of liquidity preference than to earlier Chicago analysis, thus shifting a debate about economics in the 1930s toward the center of what would soon become the highly charged "monetarist" controversy of the 1970s. This journey was completed in 1971 when Harry Johnson went considerably beyond Patinkin in pronouncing the Chicago tradition a "fabrication" designed by Friedman, "as if" to promote his own "monetarist counter-revolution," an unfortunate ad hominem attack that distracted attention from the perceptive analysis of the nature of "scientific revolutions" in economics that lay at the center of Johnson's paper.

The climax of this debate was an exchange between Patinkin and Friedman that settled some matters of genuine historical substance. ${ }^{2}$ First of all, Friedman (1974) no longer defended his 1956 " 'restatement' as 'giving the flavor of the oral tradition' at Chicago in the sense that the details of my formal structure have precise counterparts in the teachings of Simons and Mints"; indeed he asserted that Patinkin "has made a real contribution to the history of economic thought by examining and presenting the detailed theoretical teachings of Simons and Mints, and I have little quarrel with his presentation" (167), but of course Patinkin had identified the theoretical basis of monetary economics at Chicago in the 1930s as being in a then widely known quantity-theory tradition, rather than in any locally unique version of the doctrine. ${ }^{3}$ It was, in short, agreed by all concerned in 1974 that the theoretical basis of the Chicago tradition lay, as Ahiakpor

1. We suspect that the long gestation period of Patinkin's comments is related to the fact that the first edition of his Money, Interest, and Prices (1955) generated a considerable controversy that did not begin to abate until the appearance of its second edition in 1965. The defense and then revision of this work must surely have had the first claim on Patinkin's time over these years.

2. The influence of J. Ronnie Davis's (1968) analysis of the fiscal policy ideas of Chicago economists on the early stages of this controversy should also be mentioned here, perhaps. Friedman (1974) pays more than passing attention to them.

3. Robert Leeson (2003, 2:484) has suggested that Friedman's erroneous recollections of a Chicago version of the quantity theory conceived of as a theory of the demand for money might be explained by the fact that his own lecture notes from 1932 show that Lloyd Mints paid attention that year to Keynes's recently published Treatise on Money (1930), which embodied many elements of the Cambridge version of the quantity-theory tradition but also expounded a version of what, in the General Theory (1936), would become "liquidity preference" theory. 
states in his abstract (not published here) to his article in this issue, in "well-known classical and early neoclassical analysis," a fact that explains why, in our 2002 essay, we did not go into these origins and also perhaps why Friedman did not bring them up in his correspondence with us about our work.

Friedman's (1974) concessions to his critics stopped here, however. He proceeded to argue that, although the Chicago department of the 1930s had not after all developed a unique approach to monetary theory, it had nevertheless been the home of constructive and even optimistic policy analysis related to the causes and potential cures of the Great Depression. This analysis, he told his readers, was grounded in the quantity theory and had protected the department against the onset of the Keynesian revolution later in the decade, and it had also anticipated many of the ideas about the same topics subsequently developed in A Monetary History of the United States (Friedman and Schwartz 1963). In support of this claim, furthermore, Friedman $(1974,168)$ cited more than enough literature to demonstrate that this "Chicago tradition" was indeed no "fabrication," a point that he made explicitly on his own behalf.

Nevertheless, Friedman was, as Ahiakpor notes, careful to avoid claiming uniqueness for the 1930s Chicago tradition that he described in 1974. ${ }^{4}$ The earliest document he cited as epitomizing it was none other than the Harris Foundation manifesto that figures so prominently in our current dispute with Ahiakpor, and it had twenty-four signatories, only twelve of whom had Chicago affiliations. And Friedman also told his readers that he had "done no exhaustive research on the policy views of the time of economists at other institutions." Others had begun such research by then, however-for example Thomas Humphrey (1971) and Patinkin (1973) - and they had found some non-Chicago writers whose works had expounded ideas about the causes of and cures for the depression similar to those emanating from Chicago. Notable among these was Lauchlin Currie, the

4. George Tavlas (1998) was less careful in this regard, as Ahiakpor notes, claiming greater degrees of uniqueness and homogeneity for the Chicago tradition than we believe the evidence will bear, a position in which he has recently been followed by Johan van Overtveldt (2007). Much of the trouble here stems from the fact that these authors classify Paul Douglas as an exponent of the quantity theory and hence treat a 1927 paper by him advocating fiscal policy funded by money creation as an early example of the Chicago tradition's contribution. However, as Laidler (1999, 225-27) has pointed out, the theoretical inspiration acknowledged by Douglas himself for this work was not the quantity theory of money, but the under-consumptionist analysis of William Foster and Waddill Catchings (e.g., 1923). Significantly, perhaps, although Douglas was present at the Harris Foundation conference, he did not sign its manifesto. 
first-named author of the memorandum with which our 2002 work mainly dealt. ${ }^{5}$ Humphrey and Patinkin both noted, quite correctly, that Currie's works, important and penetrating though they were, had (like everything else they discussed) been published later than the key Chicago publications to which Friedman had referred, for example the 1932 manifesto and Viner 1933. Thus, although their work confirmed that the ideas associated with Friedman's Chicago tradition were not unique to that institution, local priorities in their development seemed to remain well established.

And yet the case for this, even in the light of what was known in 1974, was not quite conclusive. Currie had submitted a PhD thesis at Harvard in January 1931 that bore the title "Bank Assets and Banking Theory," and that 1932 manifesto had, after all, attracted twelve signatories from elsewhere. Curiosity about these loose ends helped prompt one of us (Laidler [1993]) to look at the matter of Chicago's priorities more closely, and in due course a number of other facts that had up till then either gone unnoticed or at least underappreciated would emerge.

5. It was at this point in the story that research on the Chicago tradition began to cross the path of another project in the history of economic thought, namely, the restoration of Currie's reputation as an important economist. As Sandilands (1990, 2004) would recount in detail, after leaving Harvard in 1934 for a spectacular career in Washington, which saw him rise from a junior position in Jacob Viner's "Freshman Brain Trust" to become, in 1939, the first personal economic adviser ever to be appointed by a president of the United States, and then on the president's behalf to take charge of U.S.-China economic relations during the war, Currie eventually fell foul of the anticommunist witch hunts of the early postwar period. In 1949 he took up a World Bank position in Colombia and settled there, becoming at the same time something of an un-person in U.S. academic circles. His publications were omitted from the "Classified Bibliography of Articles on Monetary Theory" compiled for the American Economic Association by Harlan M. Smith (1952) with "constant advice" from Lloyd Mints, and his name was nowhere mentioned in Friedman and Schwartz 1963, despite the fact that in the early 1930s, according to a recent commentator (Frank Steindl [1995]), he came closer than anyone else to anticipating their interpretation of this episode, and despite his crucially important work at the Fed, not least in the preparation of the 1935 Act of Congress that so thoroughly reformed that institution. Allan Meltzer (2003) does acknowledge Currie's contributions, and he also gets two mentions in Friedman and Schwartz's (1970) Monetary Statistics of the United States, but only as a pioneer in the construction of systematic time series data for the country's money stock. The restoration of his reputation had begun before the debate about the Chicago tradition began, with the reprinting by Earl Hamilton, Albert Rees, and Harry Johnson of his 1934 JPE article "The Failure of Monetary Policy to Prevent the Depression of 1929-32" in their Landmarks in Political Economy (1962) that celebrated the seventieth anniversary of the founding of the JPE, and the 1968 publication of a new edition of his 1934 monograph The Supply and Control of Money in the United States, with a lengthy introduction by Karl Brunner (1968). Even now, debate about Currie's political loyalties continues to impinge, unfairly we believe, on his scientific reputation (as also in the case of Harry Dexter White), as explained in Boughton and Sandilands 2003. 
First, although Currie's 1934 book was not a reprint of his 1931 thesis, at least one of its chapters, which had also been published in the Journal of Political Economy in 1933 under the title "The Treatment of Credit in Contemporary Monetary Theory," was drawn from it, while his 1934 JPE paper, "The Failure of Monetary Policy to Prevent the Depression of 1929-32," seemed to be a revised version of another; second, the immediate theoretical influence on the policy analysis presented in Currie's thesis, to judge from the citations in the version of it submitted for the degree in 1931, appeared to be Ralph Hawtrey, whose assistant Currie had been during a visiting year at Harvard (1928-29), in which he had replaced Currie's intended PhD supervisor Allyn Young, who had migrated to a chair at the London School of Economics. ${ }^{6}$ These facts were enough to establish that, late publication notwithstanding, Currie had an unassailable claim as a co-pioneer of the policy ideas associated with Friedman's Chicago tradition, influenced not so much by Fisher's American version of the quantitytheory tradition, however, as by Hawtrey's development of its (albeit closely related) Cambridge version. ${ }^{7}$

And there were other facts to be pondered: namely, that the principal supervisor of Currie's thesis had been John H. Williams, who had not only attended the 1932 Harris Foundation conference, signed its manifesto, and even participated in drafting the document, but who had also evidently played a sufficiently important part in that drafting to be asked to prepare a paper (Williams 1932) for inclusion in the conference proceedings

6. The process of restoring Young's reputation from the neglect into which it fell after his sudden and premature death in London in 1929 has also overlapped with the debate about the Chicago tradition. Thanks to the work of Charles Blitch (1995), Perry Mehrling (1997), and Mehrling and Sandilands (1999), it is now clear that by the later 1920s he was well on his way to becoming as influential a figure at Harvard as Frank Taussig, then still professionally active, although in his sixties, had been in earlier years. Young was a great admirer of Hawtrey's version of quantity-theoretic monetary analysis and had been instrumental in arranging his visiting year at Harvard.

7. Currie was particularly keen to replace Fisher's transactions version of the quantity equation by an income version that would be a better guide for the interpretation of monetary policy in the years before and during the depression. To this end Currie (1933a) estimated the first means of payment series for the United States and its related income velocity. He made use of this work in Currie 1934a where, like Hawtrey, he stressed the flows of money incomes and expenditures and showed how, in the presence of sticky wages, excessively restrictive monetary impulses could put the burden of adjustment on quantities. Hence he also criticized Hayek's "neutral money principle" that called for price falls as the way to pass on increased productivity and maintain demand ([1934] 1962, 184-86). Currie's approach also differed from Fisher's more mechanical view that fluctuations in money cause fluctuations in prices and that the problem could be solved if monetary policy could be conducted according to a simple price-stability rule (see Laidler 1999, 183-86). 
explaining its background and significance. Laidler (1993) emphasized this last fact, arguing that it pointed to the possibility of a direct Harvard (and indirect Hawtreyan) influence on the earliest publication cited by Friedman as embodying the essential message of the Chicago tradition. Laidler and Sandilands (2002a) also stress the significance of Williams's having been invited to prepare this paper, but Ahiakpor does not mention this important detail in commenting on their case.

Be that as it may, it is in just this narrow context that the Harvard memorandum becomes significant. Before this document came to general light, the main demonstrable link between Williams's input to the Harris Foundation conference and work going on at Harvard was his role in supervising Currie's $\mathrm{PhD}$ thesis, which had been completed a year earlier and seemed to expound some ideas in common with the manifesto. This evidence was suggestive, to be sure, but still left it open to a skeptical commentator such as George Tavlas $(1997,1998)$ to deny any Harvard influence on Chicago and to suggest that Currie was, in any event, a "lone wolf" at Harvard whose ideas were not representative of any more broadly based line of inquiry being followed there. The fact that the memorandum had three authors immediately disposed of this last conjecture, while the timing of its completion and the many similarities between its substance and that of the Harris manifesto increased the likelihood of there having been a Harvard influence on what Friedman had so long ago presented as an important document in the Chicago tradition.

As we noted in 2002, there is no explicit reference to the memorandum or to its authors in the records of the Harris Foundation conference, so this case is not quite conclusive, but it is surely more plausible than Ahiakpor's alternative: namely, that the timing of the completion of the two documents was coincidental, and that the above-mentioned similarities between them resulted from the application of a common analytic framework to the same policy situation by two groups of economists who were otherwise working quite independently of each other. That was our view in 2002, and evidently Friedman found it persuasive. We see no reason to retreat from it now.

\section{Forced Saving and the Quantity-Theory Tradition}

We have already expressed our agreement with Ahiakpor that lying behind the policy analysis of both the Harvard memorandum and the Chicago manifesto was a long heritage of quantity-theoretic reasoning. We also 
acknowledge that he has made a positive contribution to our understanding of how this heritage was transmitted and enhanced in the United States by drawing attention to the influence of Frank Taussig, a leading figure in the Harvard department for many years. Taussig's importance is already well understood by students of the history of balance-of-payments theory, thanks to the work of June Flanders (1989, chap. 12), but Laidler (1999, pt. 3) was surely remiss in ignoring him in his discussion of macroeconomic thought in the interwar United States.

Significantly in the current context, Flanders refers to Taussig and his students as "late classicals," explicitly linking their analysis to that of Hume, Ricardo, Mill, and Thornton, among others. ${ }^{8}$ But quantity-theoretic monetary theory was an integral part of their approach to balance-ofpayments problems, and this aspect of Taussig's influence on what would later become known as the Chicago tradition has surely received insufficient attention. He was, after all, the $\mathrm{PhD}$ supervisor of, among others, Ellsworth, Williams, and White, who figure so prominently in the specific story under discussion in this article, while Currie took his courses and had ongoing personal contact with him while a student. And Taussig was also the supervisor of Jacob Viner, who is universally acknowledged to have been a leader in the development of monetary thought at Chicago from the early 1930s onward. Perhaps, then, that department's "tradition" had even deeper Harvard roots than Laidler $(1993,1999)$ suggested.

This being said, we are troubled by Ahiakpor's systematically misleading use of the term forced saving in his discussion of the above-mentioned quantity-theoretic heritage. ${ }^{9}$ This misuse raises not just semantic questions, but issues of substance too, because, as we shall now argue, the concept of forced saving as deployed by the so-called Austrians, for example by Friedrich von Hayek ([1931] 1935, 1932, [1933] 1966), played a pivotal role in making a theoretical case against the very kind of expansionary policies espoused both by Currie and his coauthors and by the signatories of the Chicago manifesto. These Austrian ideas were expounded at the Harris Foundation conference by Gottfried von Haberler, and, even more significant for the later debate about the Chicago tradition, Friedman $(1974,163)$ would discuss them in the following terms: "It was the London

8. Flanders (1989, 241-43) errs in including James Angell, whose supervisor was Allyn Young, among Taussig's students, although like Currie, Angell was undoubtedly exposed to Taussig's teaching.

9. We believe that misuse of this term also mars another recent paper by Ahiakpor (2009) on the history of Phillips curve analysis, but further discussion of this suggestion here would take us too far beyond the bounds of this article to be feasible. 
School (really Austrian) view that I referred to in my 'Restatement' when I spoke of 'the atrophied and rigid caricature' [of the quantity theory] that is so frequently described by the proponents of the new income-expenditure approach-and with some justice, to judge by much of the literature on policy that was spawned by the quantity theorists. The intellectual climate at Chicago had been wholly different"- to which we would add, judging from the memorandum and Currie's other work of the period, at Harvard too. ${ }^{10}$

Now Friedman's characterization of Austrian theory itself as a version of the quantity theory of money was surely inappropriate in the light of the Austrians' own explicitly expressed doubts about the adequacy of the latter (see, e.g., Hayek [1931] 1935, 3-8), but it is certainly the case that the analysis of forced saving that was central to their theory of economic crises had begun as an offshoot of quantity-theoretic work. Crucially, however, this forced-saving idea is not the doctrine to which Ahiakpor affixes the label. For him, what he calls "the forced-saving mechanism" is synonymous with "the lagged adjustment of wages behind prices" or, more extensively, "the forced-saving mechanism-the lagged adjustment of wage rates, interest rates, and rental rates behind changes in the price level... produces the short-term effects on output and employment from variations in the quantity of money and credit." This usage leads him to link together as exponents of the forced-saving doctrine a long line of acknowledged quantity theorists stretching from David Hume (1752) - "There is always an interval before matters be adjusted to their new situation; and this interval is as pernicious to industry, when gold and silver [money] are diminishing, as it is advantageous when these metals are increasing" (as quoted by Ahiakpor) - to Frank Taussig (1921, 298-99): "That wages go up more slowly than prices is one of the best attested facts in economic history. ... To the extent that prices of commodities advance faster than expenses for the labor [employers] buy, the payers of wages gain" (as quoted by Ahiakpor). ${ }^{11}$

The trouble is that the passages Ahiakpor quotes here express not the forced-saving doctrine as it has usually been understood, but what sometimes is called the "wage-lag hypothesis," and indeed at two points in his

10. Friedman's reference to the "London School" must be read in the light of the fact that in this passage he was discussing the contrast between what he had learned at Chicago in the early 1930s and what Abba Lerner had learned in the same years at LSE where the economic analysis of the depression was of course dominated by Hayek and Robbins (1934).

11. The attentive reader will note that we here abbreviate the passages that Ahiakpor quotes, without we hope affecting the argument in any way. 
essay, Ahiakpor recognizes that there might be some debate about treating these two ideas as if they were the same. Thus he acknowledges that "some modern analysts tend to separate the lagged wage adjustment behind product prices from the classical forced-saving doctrine, e.g., Humphrey (1982), Hansson (1987), and Laidler (1991, 1993, 1999)," but he immediately goes on to say, "see Hayek [1933] 1966, 218-19 n, for some identifications of the equivalence," and he claims that "Ahiakpor 2009 further explains the equivalence." He also warns his readers that "some analysts, including some previous referees, do not recognize the forcedsaving mechanism in Hume's monetary analysis" (n. 13). But he then assures them that "I here follow David Ricardo's (4:36) lead in doing so. See also Hayek [1931] 1935, 9, and Roll [1938] 1992, 103.” Ahiakpor also cites Hayek [1931] 1935, 25 n, as recognizing Taussig's claims to be an exponent of the forced-saving doctrine on the strength of those sections of his textbook (Taussig 1921) from which the quotation noted above is taken-specifically chapter 22, especially sections 5-6 (pp. 294-301).

Now even today, Hayek is acknowledged to be a leading authorityperhaps the leading authority-on the early development of the forcedsaving doctrine. ${ }^{12}$ Thus, Ahiakpor seems at first sight to have considerable scholarly authority behind the terminology he adopts and the intellectual links he makes. In fact, however, the Hayekian sources he cites offer him no support at all. The footnote in Hayek [1933] 1966, 218-19 n, which is said to "offer some equivalence" between lagged wage adjustment and the forced-saving doctrine, does nothing of the sort; it sets out a highly abbreviated history of the early development of the forced-saving doctrine based on Hayek 1932 and makes no mention of lagged wage adjustment. The passage in Hayek 1931, 9, that is said to recognize the presence of the forcedsaving doctrine in Hume's analysis discusses the effects of lagging wages on output when prices are rising, but makes no use of the term forced saving (and in any case seems not to recognize that Hume was actually dis-

12. As Ahiakpor notes in his footnote 4, citing Viner $(1937,188)$ as his authority. The article that Viner in turn cites is, of course, Hayek 1932. However, in his own review of the earlynineteenth-century bullionist controversy in the same book, Viner explicitly distinguished two forms of the argument that "an increase in the quantity of money operates to increase employment and prosperity." The first was the newly introduced "forced-saving" doctrine in which investment is increased at the expense of those on fixed incomes; the second was the argument that "commodity prices do not rise immediately or do not rise in as great proportion as the increase in money, and the money left over is available for additional expenditures and consequently for the employment of additional labor. This form of the doctrine, of course, was not novel, but goes back to Hume ... and rests on the assumption that there are idle resources." 
cussing the likelihood, if gold flows into a country due to a payment surplus, that wages would rise before a rise in prices); and Hayek's citation of Taussig in Hayek [1931] 1935, 25 n, to which Ahiakpor explicitly refers, is to page 351 (chap. 25) of that book, where forced saving is indeed discussed, and to page 359, where it is not (see, however, p. 399). Hayek's citation is not to the passages in Taussig-pages 294-301-on which Ahiakpor focuses - where the wage-lag hypothesis alone is discussed.

Nor do the passages in the writings of David Ricardo ([1815] 1951) and Eric Roll ([1938] 1992) that Ahiakpor invokes serve his case any better. To the extent that there is anything relevant to the current discussion to be found on page 36 of volume 4 of Ricardo's Works and Correspondencethe passage in question occurs in his 1815 "Essay on Profits," which is concerned with the effects of variations in the relative price of corn on profits - it might be the following: "Mr Malthus notices an observation, which was first made by Hume, that a rise in prices has a magic effect on industry: he states the effects of a fall to be equally depressing." As to Roll's ([1938] 1992, 103) discussion, which seems to have remained unchanged since the first (1938) edition of his book, this revolves around the following quotations from Hume: "It is only in this interval or intermediate situation, between the acquisition of money and rise of prices, that the increasing quantity of gold and silver is favourable to industry" and "[the increase of money] will quicken the diligence of every individual, before it encrease the price of labour." Roll interprets Hume as here describing "what Keynes later called a profit inflation which was taking place at the expense of labour," but Morris Perlman (1987) has argued persuasively that the word "labour" in the above quotation from Hume should be read as meaning "the output of labour," which would invalidate Roll's interpretation. In any event, none of this has anything to do with forced saving.

Even so, elsewhere in the specific works of Hayek to which Ahiakpor refers, there are extensive discussions of forced saving: of the term's meaning, of the origins of the doctrine that it signifies, and of that doctrine's apparent implications for both theory and policy. Thus in the very passage of Monetary Theory and the Trade Cycle ([1933] 1966) to which the above-mentioned footnote (pp. 218-19 n) is attached, Hayek writes as follows: "The phenomenon of 'forced saving' ... has received a great deal of attention in recent literature. This phenomenon, we are led to understand, consists in an increase in capital creation at the cost of consumption, through the granting of additional credit, without voluntary action on the 
part of the individuals who forgo consumption, and without deriving any immediate benefits" (218-19). Or as he describes the same theory of forced saving-again he deploys the term explicitly_more succinctly in Prices and Production ([1931] 1935, 18), "an increase in money brings about an increase in capital." And in both places, Hayek identifies the doctrine's originators as Jeremy Bentham, who finished writing the relevant passage in 1804, although it was not published until 1843, Henry Thornton (1802), and particularly Thomas Malthus (1811), to whom he accords "the honour of first having discussed the problem in some detail in print ... with the complaint that no writer he is acquainted with "has ever seemed sufficiently aware of the influence which a different distribution of the circulating medium of the country must have on those accumulations which are destined to aid future production"' (19). There is no hint here, nor in any of Hayek's other writings of the period (1932, [1933] 1966), at a Humean origin for this doctrine, or at any equivalence to the wage-lag doctrine that he had discussed only a few pages earlier.

Given the amount of attention that Ahiakpor pays to Frank Taussig, it is worth pointing out that he also refers to a passage in Dennis Robertson's Banking Policy and the Price Level ([1926] 1960, 52) in support of his own attribution of the forced-saving idea to Taussig, which, as we have seen, he bases on a passage from Taussig 1921, 298-99. Robertson there quotes, with abbreviations, a brief passage that appears on page 351 of this edition of Taussig's book, which is nowhere near pages 298-99. This passage, presumably the one to which Hayek (1931) also refers (see above), reads: "So far as deposits are created by the banks ... money means are created, and the command of capital is supplied, without any cost or sacrifice on the part of any saver." This is indeed a version of the forced-saving doctrine, although Robertson, himself an exponent of an unusually subtle analysis of the phenomenon under the label "imposed lacking," found it "far too sweeping." 13

It is not Robertson's deployment of the forced-saving idea in the mid1920s that is crucial to matters under discussion here, however, but that

13. Robertson locates the relevant passage on page 357, with no edition specified, but it does appear on page 357 of Taussig's second (1915) edition. The key point here, however, is that the passage in question is unrelated to Taussig's discussion of the wage-lag doctrine on which Ahiakpor himself focuses. Of course, forced-saving theory usually does require someone to make an involuntary sacrifice of current consumption when investments are financed through credit creation, and it is true as well that an economy that is subject to wage lags may also be subject to such a process. But wage lags are neither necessary nor sufficient for forced saving to occur. 
of the Austrians, including Hayek, in the early 1930s. As we have already noted, they were deeply skeptical of the adequacy of quantity-theoretic reasoning of the type that underlay both the Harvard memorandum and the Harris manifesto (see, e.g., Hayek [1931] 1935, 1-7); and they also vigorously opposed the sort of expansionary monetary policies that were advocated in both documents-"well meaning but dangerous proposals to fight depression by 'a little inflation,'” as Hayek ([1931] 1935, 125) famously termed such recommendations. ${ }^{14}$ Crucially, Austrian skepticism on these points derived from a particular application of the forced-saving doctrine (as properly understood) to the analysis of the business cycle. As Hayek ([1933] 1966, 218-26) explained, early exponents of the doctrine had tended to treat the process of capital accumulation to which forced saving gave rise as benign, or even helpful in achieving well-balanced economic growth, inasmuch as it tended to drive down the Wicksellian "natural rate of interest," but the Austrians, beginning with Ludwig von Mises (1912), took a very different view, namely that "it is probably more proper to regard forced saving as the cause of economic crises than to expect it to restore a balanced structure of production" (Hayek [1933] 1966, 226; italics in original).

To put the analytic basis of this view succinctly, the Austrians believed that the capital accumulation generated by forced saving would be accompanied by a growing excess demand for current consumption goods and a correspondingly expanding capacity to supply future consumption goods that no one wanted, and that it could only be kept going by a rising and ultimately unsustainable rate of credit creation by the banking system. When such an inflationary boom came to its inevitable end, a crisis would ensue whose essential characteristics would include an excessive stock of capital, some of it embodied in uncompleted projects, and an excess demand for consumption goods as well. Hence, policies designed to stimulate demand in the wake of such a crisis could only make matters worse and were to be eschewed while the passage of time restored equilibrium to the time structure of production.

In short, in the early 1930s, far from forming the centerpiece of a quantity-theoretic tradition from which the case for the expansionary

14. In an otherwise sympathetic review of Currie's 1934 book-he was particularly complimentary about the chapter on confusions between money and credit that had also appeared as Currie 1933b-Robertson (1935) worried about a potentially dangerous "inflation-bacillus" in Currie's blood that colored his outline of an "ideal" plan for more effective, centralized monetary control-with 100 percent reserves required against demand deposits - to deal with the problem of cyclical fluctuations. 
policies recommended in both the Harvard memorandum and the Harris manifesto derived, the forced-saving doctrine, as properly interpreted, lay at the very heart of a body of theoretical and policy doctrine that was root-and-branch opposed to all that these documents represented in the monetary economics of the time. Ahiakpor's misuse of the term, and his consequent misinterpretation of the doctrine that it characterizes, obscure this all-important fact and are not minor matters.

\section{Constructive Policy Proposals and Others}

At one point in his essay, Ahiakpor claims that "Hume's analysis ... provides the basic framework for a remedial policy formulation in the case of a commercial crisis of the type experienced during the Great Depression." This is surely going too far. Had it been that easy, there would have been little need for the bullionist and currency school-banking school controversies, not to mention those later debates in the course of which the theories of money, banking, and central banking as they stood by the end of World War I had developed. ${ }^{15}$ Nevertheless such remedial policy recommendations do indeed weave in and out of the monetary literature, if not from the mid-eighteenth century onward, certainly from the very beginning of the nineteenth. More often than not, however, they were a minority taste among exponents of the evolving monetary orthodoxy of the following century and a quarter. Of no place and time is this more true than of the United States at the onset of the Great Depression, and Ahiakpor's failure to grasp this fact contributes to his underestimation of the importance of the Harvard memorandum and of the Harris manifesto too.

At that time, the Austrians had a new theory with which to justify the case against expansionary monetary and fiscal policies, and this was making their work particularly attractive to and influential among academic economists. But the anti-activist policy position itself long antedated their new theory, and it resonated much more broadly too, among bankers and policy makers, many of whom had probably never heard of forced saving and would have cared little about the theoretical significance of the concept if they had. It derived from what is often called a "banking school" tradition that is almost as venerable as the quantity theory of money and whose exponents often made the so-called real-bills or needs-of-trade

15. Any reader tempted to accept Ahiakpor's suggestion that we "overlooked the classical and early neoclassical source from which Currie and his coauthors drew their insights" might consult Laidler 1991 and 2000 as guides to these sources alternative to the one he provides. 
doctrine a central feature of their work. ${ }^{16}$ Important in the current context, this theory of monetary policy had become the dominant one in the United States in the wake of the bimetallic controversy of the 1880s and 1890s, and, under the influence of James Laurence Laughlin, the founding chairman of the Chicago economics department, and with direct input from Laughlin's sometime Chicago PhD student Henry Parker Willis, it had even become embodied in the Federal Reserve Act of 1913. ${ }^{17}$

The essential feature of this doctrine was the proposition that a monetary policy that ensured that the supplies of money and credit responded with elasticity to the "needs of trade" would always be stabilizing, and as a corollary that became centrally important in the early years of the depression, that efforts actively to expand money and credit beyond the needs of trade might affect prices but do nothing for the performance of the real economy.

So dominant had this view become in the United States in the first two decades of the twentieth century that Irving Fisher characterized his now famous monograph The Purchasing Power of Money (1911) as an effort to rehabilitate its then widely discredited quantity-theoretic rival, and he treated Laughlin's work as a foil for his own. Although Fisher's arguments made some headway among academics in the 1920s, and although advocates of "credit control"-an approach to monetary policy that involved its deployment as an active tool of stabilization-such as Allyn Young even got a hearing for their ideas within the Federal Reserve System, the needsof-trade doctrine nevertheless remained dominant there and in financial circles more generally. As Friedman and Schwartz (1963) and Meltzer (2003) have thoroughly documented, moreover, this doctrine provided the intellectual underpinning for the usually passive policy stance taken by the Federal Reserve at the time at which the Harvard memorandum and the Harris manifesto were prepared.

Laughlin, by then in his eighties and long retired from the Chicago department, provided a particularly clear-cut statement of the doctrine

16. Lloyd W. Mints (1945), surely one of the most distinguished products of the Chicago tradition under discussion in this article, remains a classic source on the historical development of this doctrine and alternatives to it. Note, however, that not all those who have been classified as members of the banking school by Mints and others were also committed to the real-bills doctrine. On this matter, see Skaggs 2010. Exponents of this doctrine often failed to distinguish clearly between credit and money, and such confusion often lay at the roots of their support for essentially passive monetary policy. This is the main theme explored and clarified in Currie's (1933b) quantity-theoretic treatment of these issues.

17. On the importance of such views in the debate that preceded the founding of the Federal Reserve System in 1913, see Dimand 2003. 
and its implications for contemporary policy issues in his 1933 book The Federal Reserve Act: Its Origins and Problems: "Perhaps the commonest fallacy is that the more of the medium of exchange issued by a public authority, the greater the purchasing power of the people, the greater the demand for goods and the higher the level of prices.... In reality demand comes from other goods, before money or credit enter on the scene" (219-20), so that "to increase the medium of exchange as a remedy when there are less goods to be exchanged is fatuous" (285). Although Willis (1932) did not express himself quite as bluntly at the Harris conference, this was nevertheless the message he conveyed, and he spoke for a majority of policy makers and men of influence when he did so.

The historical importance of both the Harvard memorandum and the Harris manifesto (and of a number of other documents circulating at around the same time) lay not just in the quality of the intellectual effort that went into deriving policy proposals for the times from a long-standing intellectual tradition of quantity-theoretic work, but in the fact that those proposals laid out specific and positive plans of action for dealing with the then accelerating downturn. Moreover, and crucially, these plans were, in the words that Friedman $(1974,163)$ would later use to characterize the manifesto and subsequent Chicago work too, "hopeful and relevant" in contrast to the "dismal picture" implicit in an alternative view that "the only sound policy was to let the depression run its course, bring down money costs, and eliminate weak and unsound firms."

In the early 1930s, hope and relevance were thus important qualities in their own right, but because their importance was enhanced when they were married to coherent economic analysis, departments of economics whose members could provide a combination of all these qualities were likely to prosper intellectually. That is why we still believe that Harvard did itself no good when it let Currie, White, and Ellsworth leave, while retaining the nevertheless distinguished authors of The Economics of the Recovery Program (Brown et al. 1934). Despite Ahiakpor's attempts to defend the latter work, we still find it unimpressive. This is not just because its most coherent chapter, that prepared by the then recently appointed Joseph Schumpeter, was devoted to expounding an Austrian-style case for policy passivity, but because, as Ahiakpor himself acknowledges, its contributors as a whole were content to pick holes in the "Recovery Program" in question without feeling the need to "suggest measures of remedial policy. We do not see any force in the question: What remedies have you yourselves to offer? Analysis and criticism have their place independently of the existence or nature of alternative proposals" (1934, xii, as quoted by 
Ahiakpor in his footnote 1). Perhaps they do have their place, but in the middle of the Great Depression, when the economic and political situation was crying out for just such alternative proposals, the place in question was surely a rather humble and obscure one reserved for the mediocre.

Small wonder, then, that the Harvard department whose own remaining members after 1934 had no positive ideas to offer about the central economic questions of the day would soon succumb to those who did, namely, the young Keynesians led by Alvin Hansen who would quickly come to dominate it after 1936. Whether this was for good or ill, however, and whether Harvard economics developed along more or less constructive lines than did the Chicago version in the late 1930s and 1940s are questions that we are content to leave for another day.

\section{References}

Ahiakpor, James C. W. 2009. The Phillips Curve Analysis: An Illustration of the Classical Forced-Saving Doctrine. Journal of the History of Economic Thought 31 (June): 143-60.

Bentham, Jeremy. [1804] 1843. Manual of Political Economy. Vol. 3 of The Works of Jeremy Bentham. Edinburgh: W. Tait.

Blitch, Charles P. 1995. Allyn Young: The Peripatetic Economist. Houndmills: Macmillan.

Boughton, James M., and Roger J. Sandilands. 2003. Politics and the Attack on FDR's Economists: From Grand Alliance to Cold War. Intelligence and National Security 18.3:73-99.

Brown, Douglass V., et al. 1934. The Economics of the Recovery Program. Cambridge: Harvard University Press.

Brunner, Karl. 1968. On Lauchlin Currie's Contribution to Monetary Theory. Introduction to The Supply and Control of Money in the United States, by L. Currie, ix-xxxv. New York: Russell \& Russell.

Currie, Lauchlin. 1931. Bank Assets and Banking Theory. PhD diss., Harvard University.

- 1933a. Money, Gold, and Incomes in the United States, 1921-32. Quarterly Journal of Economics 48 (November): 77-95.

- 1933b. The Treatment of Credit in Contemporary Monetary Theory. Journal of Political Economy 41.1:509-25.

- 1934a. The Failure of Monetary Policy to Prevent the Depression of 1929-32. Journal of Political Economy 42.2:145-77.

- 1934b. The Supply and Control of Money in the United States. Cambridge: Harvard University Press.

_. [1934] 1962. The Failure of Monetary Policy to Prevent the Depression of 1929-32. In Landmarks in Political Economy, edited by Earl J. Hamilton, Albert Rees, and Harry G. Johnson, 168-98. Chicago: University of Chicago Press. 
. [1934] 1968. The Supply and Control of Money in the United States. New York: Russell \& Russell.

Davis, J. Ronnie. 1968. Chicago Economists, Deficit Budgets, and the Early 1930s. American Economic Review 58 (June): 476-82.

Dimand, Robert. 2003. Competing Visions for the U.S. Monetary System, 1907-1913: The Quest for an Elastic Currency and the Rejection of Fisher's Compensated Dollar Rule for Price Stability. Cahiers d'économie politique 35 (Autumn): 191-211.

Douglas, Paul H. 1927. The Modern Technique of Mass Production and Its Relation to Wages. Proceedings of the Academy of Political Science in the City of New York 12.3:17-42.

Fisher, Irving. 1911. The Purchasing Power of Money. New York: Macmillan.

Flanders, M. June. 1989. International Monetary Economics, 1870-1960: Between the Classical and the New Classical. Cambridge: Cambridge University Press.

Foster, William T., and Waddill Catchings. 1923. Money. Boston: Houghton Mifflin.

Friedman, Milton. 1956. The Quantity Theory of Money-a Restatement. In Studies in the Quantity Theory of Money. Chicago: University of Chicago Press.

- 1974. Comments on the Critics. In Milton Friedman's Monetary Framework, edited by Robert J. Gordon, 132-77. Chicago: University of Chicago Press.

Friedman, Milton, and Anna J. Schwartz. 1963. A Monetary History of the United States, 1867-1960. Princeton, N.J.: Princeton University Press.

-1970. The Monetary Statistics of the United States: Estimates, Sources, Methods. New York: NBER.

Hamilton, Earl J., Albert Rees, and Harry G. Johnson, eds. 1962. Landmarks in Political Economy. Chicago: University of Chicago Press.

Hansson, Björn. 1987. Forced Saving. In The New Palgrave: A Dictionary of Economics, edited by John Eatwell, Murray Milgate, and Peter Newman. London: Palgrave Macmillan.

Hayek, Friedrich A. von. 1931. Prices and Production. London: Routledge.

- 1932. A Note on the Development of the Doctrine of "Forced Saving." Quarterly Journal of Economics 47 (November): 123-33.

- [1931] 1935. Prices and Production. 2nd ed. London: Routledge.

- . [1933] 1966. Monetary Theory and the Trade Cycle. Translated by N. Kaldor and H. Croome. Reprint, New York: Augustus M. Kelley.

Hume, David. 1752. Political Discourses. Edinburgh: A. Kinkaid and A. Donaldson.

Humphrey, Thomas M. 1971. Role of Non-Chicago Economists in the Evolution of the Quantity Theory in America, 1930-1950. Southern Economic Journal 38 (July): 12-18.

- 1982. Of Hume, Thornton, the Quantity Theory, and the Phillips Curve. Federal Reserve Bank of Richmond Economic Review 54 (November-December): 13-18.

Johnson, Harry G. 1971. The Keynesian Revolution and the Monetarist CounterRevolution. American Economic Review, Papers and Proceedings 61 (May): 1-14. Keynes, John Maynard. 1930. A Treatise on Money. London: Macmillan. . 1936. The General Theory of Employment, Interest, and Money. London: Macmillan. 
Laidler, David. 1991. The Golden Age of the Quantity Theory. Hemel Hempstead: Philip Allan.

- 1993. Hawtrey, Harvard, and the Origins of the Chicago Tradition. Journal of Political Economy 101 (December): 1068-1103.

- 1999. Fabricating the Keynesian Revolution: Studies of the Inter-war Literature on Money, the Cycle, and Unemployment. Cambridge: Cambridge University Press.

- 2000. Highlights of the Bullionist Controversy. Research Report, no. 13. Stockholm School of Economics, Institutet for Economisk Historisk Forskning.

Laidler, David, and Roger J. Sandilands. 2002a. An Early Harvard Memorandum on Anti-depression Policies: An Introductory Note. HOPE 34.3:515-32.

— , eds. 2002b. Memorandum Prepared by L. B. Currie, P. T. Ellsworth, and H. D. White (Cambridge, Mass., January 1932). HOPE 34.3:533-52.

Laughlin, James L. 1933. The Federal Reserve Act: Its Origins and Problems. New York: Macmillan.

Leeson, Robert. 2003. Keynes, Chicago, and Friedman. 2 vols. London: Pickering and Chatto.

Malthus, Thomas R. 1811. Review of David Ricardo's High Price of Bullion. Edinburgh Review 17.34.

Mehrling, Perry G. 1997. The Money Interest and the Public Interest: American Monetary Thought, 1920-1970. Cambridge: Harvard University Press.

Mehrling, Perry G., and Roger J. Sandilands, eds. 1999. Money and Growth: Selected Papers of Allyn Abbott Young. London: Routledge.

Meltzer, Allan H. 2003. A History of the Federal Reserve. Vol. 1, 1913-1951. Chicago: University of Chicago Press.

Mints, Lloyd W. 1945. History of Banking Theory. Chicago: University of Chicago Press.

Mises, Ludwig von. 1912. Theorie des Geldes und der Umlaufsmittel. Munich: Dunker und Humblot.

—. [1912] 1924. Theory of Money and Credit. 2nd rev. ed. Translated by H. E. Batson. London: Jonathan Cape.

Patinkin, Don. 1955. Money, Interest, and Prices: An Integration of Monetary and Value Theory. Evanston, Ill.: Row, Peterson and Co.

- 1969. The Chicago Tradition, the Quantity Theory, and Friedman. Journal of Money, Credit, and Banking 1 (February): 46-70.

- 1973. More on the Chicago Monetary Tradition. Southern Economic Journal 39 (January): 454-59.

Perlman, Morris. 1987. Of a Controversial Passage in Hume. Journal of Political Economy 95.2:274-89.

Ricardo, David. [1815] 1951. An Essay on the Influence of a Low Price of Corn on the Profits of Stock. In vol. 4 of The Works and Correspondence of David Ricardo, edited by P. Sraffa, 1-41. Cambridge: Cambridge University Press.

Robbins, Lionel C. 1934. The Great Depression. London: Macmillan.

Robertson, Dennis H. 1935. Review of The Supply and Control of Money in the United States, by L. B. Currie. Economic Journal 45 (March): 128-31. 
. [1926] 1960. Banking Policy and the Price Level. Reprint, New York: Augustus M. Kelley.

Roll, Erich. 1938. A History of Economic Thought. London: Faber and Faber.

Roll, Eric. [1938] 1992. A History of Economic Thought. 5th ed. London: Faber and Faber.

Sandilands, Roger J. 1990. The Life and Political Economy of Lauchlin Currie: New Dealer, Presidential Adviser, and Development Economist. Durham, N.C.: Duke University Press.

- 2004. Editor's Introduction to "New Light on Lauchlin Currie's Monetary Economics in the New Deal and Beyond." Journal of Economic Studies 31.3-4: 170-93.

Skaggs, Neil. 2010. Less Than an Ideal Type: Varieties of Real Bills Doctrines. In David Laidler's Contributions to Economics, edited by Robert Leeson, 260-78. Houndmills: Palgrave Macmillan.

Smith, Harlan M. 1952. Classified Bibliography of Articles on Monetary Theory. In Readings in Monetary Theory, edited by F. A. Lutz and L. W. Mints. London: George Allen and Unwin.

Steindl, Frank G. 1995. Monetary Interpretations of the Great Depression. Ann Arbor: University of Michigan Press.

Taussig, Frank W. 1915. Principles of Economics. 2 vols. 2nd ed. New York: Macmillan.

- 1921. Principles of Economics. 2 vols. 3rd ed. New York: Macmillan.

Tavlas, George S. 1997. Chicago, Harvard, and the Doctrinal Foundations of Monetary Economics. Journal of Political Economy 105 (February): 153-77.

- 1998. Retrospectives: Was the Monetarist Tradition Invented? Journal of Economic Perspectives 12.4:211-22.

Thornton, Henry. 1802. An Enquiry into the Nature and Effects of the Paper Credit of Great Britain. London: J. Hatchard.

Van Overtveldt, Johan. 2007. The Chicago School: How the University of Chicago Assembled the Thinkers Who Revolutionized Economics and Business. Chicago: Agate Publishing.

Viner, Jacob. 1933. Balanced Deflation, Inflation, or More Depression? Minneapolis: University of Minnesota Press.

- 1937. Studies in the Theory of International Trade. New York: Harper.

Williams, John H. 1932. Monetary Stability and the Gold Standard. In Gold and Monetary Stabilization: Lectures on the Harris Foundation, edited by Quincy Wright. Chicago: University of Chicago Press.

Willis, Henry Parker. 1932. Federal Reserve Policy in Depression. In Gold and Monetary Stabilization: Lectures on the Harris Foundation, edited by Quincy Wright. Chicago: University of Chicago Press. 